\title{
Culture conditions affect the nutritional value of the copepod Acartia tonsa
}

Arne M. Malzahn ${ }^{1,2, *}$, Nicole Aberle-Malzahn² ${ }^{2}$ Katherina Schoo ${ }^{1,3}$, Maarten Boersma ${ }^{2}$

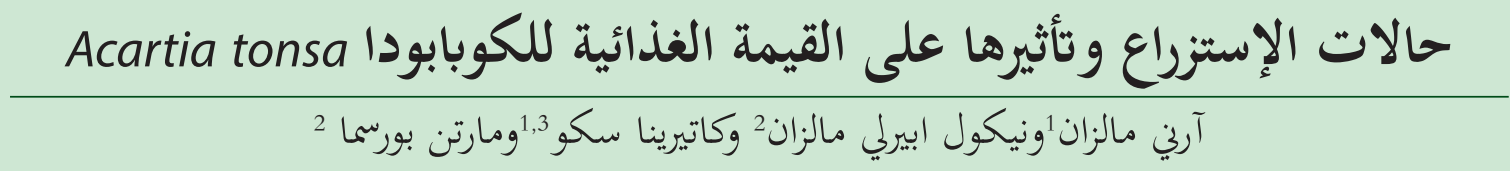

AbSTRACT. Live feed are still necessary for the rearing of larval stages of several fish species, especially marine ones. Compared to Artemia, copepods are of superior quality. This is based on a suite of traits like size, movement, and nutritional value. Copepods are for example usually high in protein and fatty acids. Essential fatty acid profiles reflect to a large degree the fatty acid supply, which provides the opportunity to manipulate fatty acid profiles of, amongst others, copepods. By manipulating nutrient supply of the algae Rhodomonas salina we were able to double essential fatty acid concentrations in naupliar and copepodit life stages of the copepod Acartia tonsa. However, this lead to growth depression rather than to increased growth rates in a series of consumer species, including larval fish. The reason for the growth depression is likely to be mineral deficiencies occurring along with the nutrient manipulation of the algae.

Keywords: copepod, nutritional value, live feed, aquaculture, Acartia

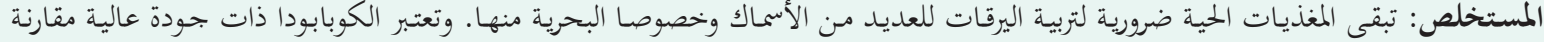

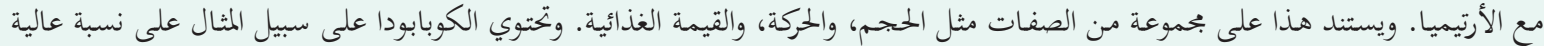

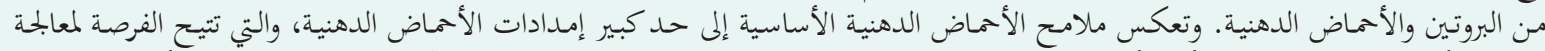

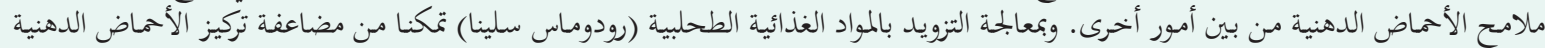

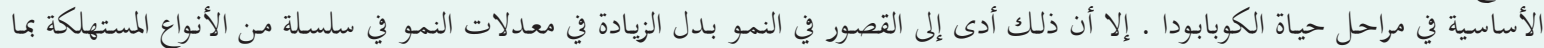

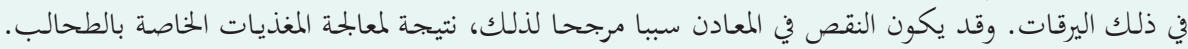

$$
\begin{aligned}
& \text { الكلمات المفتاحية: غراء الببتيدات، السيلوكسانات، الخاصة بالطحالب. }
\end{aligned}
$$

\section{Introduction}

$\mathrm{T}$ he global yield of the capture fisheries has been stagnating at around 85 million metric tonnes per year since the mid 1980ies. Since more or less the same time, aquaculture production is on an exponential rise, replacing the missing growth in capture fisheries production (Fig. 1). The vast majority of the 80 million tons of aquaculture production in 2010 was made up by seaweeds and cyprinid fishes (20 and 25 million tonnes respectively) (Fao). However, focussing on the value per unit the picture completely changes and next to the high value products such as abalone, shrimps and sturgeons with values between 20,000 and 50,000 US\$ tonne-1 we find species such as groupers, soles and pompanos in the same price range. The main difference between the first and the latter group is that the first is relatively

${ }^{1}$ Department of Marine Science \& Fisheries, College of Agricultural and Marine Sciences, Sultan Qaboos University, P.O. Box 34, PC:123 Al-Khod. Arne Malzahn ( $(\checkmark)$ email: arne.malzahn@gmail.com

${ }^{2}$ Alfred Wegener Institute for Polar and Marine Research, Ostkaje 1118, 274.98 Helgoland, Germany

${ }^{3}$ Shannon Point Marine Center, Western Washington University, 1900 Shannon Point Road, Anacortes, WA 98221, USA. easy to culture and the price is based on slow growth and relatively low area based biomass production. The latter group of groupers, soles and jacks have in common that they are sought after food fish with dwindling stocks and that they are not easy to grow, reproduce and wean in captivity. One of the bottlenecks for instance in grouper culture is the larval weaning (Sugama et al. 2012), and they, like many other species, rely on live feeds (Lavens and Sorgeloos 1996; Lavens et al. 1994). This is mirrored by the still increasing number of publications on the use of live feeds in aquaculture (Fig. 2). The typical succession of live feeds for very small, gape limited larvae is to start with ss-type or s-type Brachionus spp., followed by larger Brachionus spp. strains and eventually Artemia spp. larval stages (Lavens and Sorgeloos 1996; Lavens et al. 1994). Artemia and Brachionus species are not always the most suitable first feeds for marine fish larvae due to inappropriate size (Pepin and Penney 1997; Van Der Meeren 1991), their swimming behaviour, which makes them less susceptible to predation (Buskey et al. 1993; Von Herbing and Gallagher 2000), and they are suspected of being of insufficient nutritional quality (Støttrup and Norsker 1997). Calanoid copepods as live feed have been shown to improve growth and survival in groupers (Doi et al. 1997), and several other species (Stottrup 


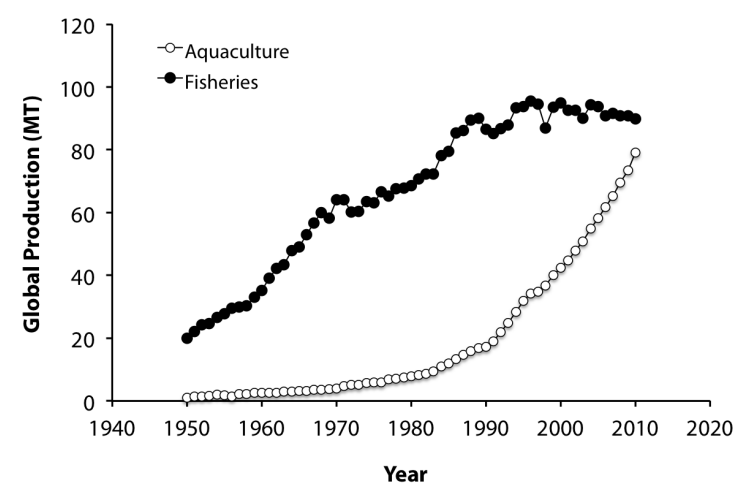

Figure 1. Global wild fish capture and aquaculture production in million tonnes, 1950-2010. Data source: FAO (Fao).

2000), and larval grouper actively select for copepod nauplii over rotifers (Toledo et al. 2004). Similar selectivity patterns have been reported for a suite of marine fish larvae (Monteleone and Peterson 1986; Stoecker and Govoni 1984).

Food quality can be expressed in many ways, such as through the concentration of polyunsaturated fatty acids (Paulsen et al. 2014; Paulsen et al. 2013), sterols (Lee 2001), amino acids (Awaiss et al. 1992) or the elemental composition (Malzahn et al. 2007; Shao et al. 2008) of the food item. All of the latter play a major role in fish nutrition (Lavens et al. 1994), and it is crucial to find the food organisms which suits the demand best. It is very likely that marine copepods are a good match for the nutritional demands of larval fish as they are the main prey items in nature, hence an adaptation of the needs of larval fish to the main prey in supply can be assumed. Wild zooplankton has been successfully used for larval rearing (Otterlei et al. 1999) with growth rates superior compared to Artemia larvae. However, availability of natural zooplankton is a problem, as zooplankton size spectrum (Beaugrand et al. 2002; Greve et al. 2004), density (Beaugrand et al. 2003) and species composition (Beaugrand et al. 2002; Greve et al. 2004) are permanently changing. Even if the supply of natural

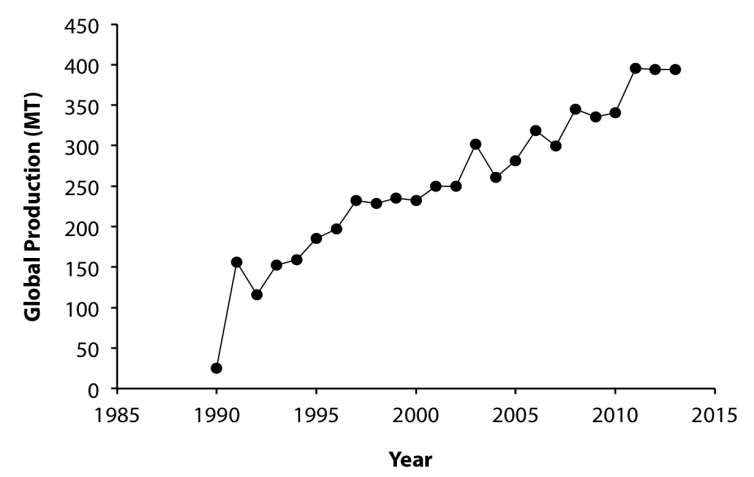

Figure 2. Number of publications retrieved from Web of Science using the search words 'aquaculture' and 'live feeds'

zooplankton was reliable, the nutritional value of copepods varies with species (Gismervik 1997a; Gismervik 1997b), life stage (Villar-Argaiz et al. 2002; Villar-Argaiz and Sterner 2002) and season (Villar-Argaiz et al. 2002; Villar-Argaiz and Sterner 2002) and is hence again an unreliable source of live feeds. Consequently, in-house life feed production in the form of copepods seems to be a reliable way to fulfil the nutritional demand of early life stages of fish until they can be weaned on more easily accessible live feeds like Brachionus and Artemia or even formulated diets.

This paper aims to sum up a series of experiments carried out to determine how copepod culture conditions can be manipulated to produce copepods of an elemental and biochemical composition of choice.

\section{Materials and methods}

We conducted a series of experiments in which copepods were fed on phytoplankton which in turn was grown in nutrient manipulated growth media. The data we show here are representative for the nutrient treatments and can easily be reproduced. The phytoplankter $R$. salina was reared either under nutrient replete conditions using the $\mathrm{f} / 2$ medium following Guillard and Ryter

Table 1. Fatty acid concentrations and elemental ratios of phytoplankton grown on nutrient replete (f/2) and nutrient depleted $(-\mathrm{P}$ and $-\mathrm{N})$ media.

\begin{tabular}{|c|c|c|c|c|c|c|}
\hline Measure & $\mathbf{f} / 2$ & $+/-\mathbf{s d}$ & $-\mathbf{N}$ & $+/-\mathbf{s d}$ & $-\mathbf{P}$ & $+/-\mathbf{s d}$ \\
\hline sum unsaturated FA ( $\left.\mu \mathrm{g}^{*} \mu \mathrm{gC}-1\right)$ & 0.035 & 0.022 & 0.066 & 0.032 & 0.105 & 0.079 \\
\hline total FA $\left(\mu g^{*} \mu g C-1\right)$ & 0.058 & 0.023 & 0.145 & 0.056 & 0.146 & 0.090 \\
\hline $20: 5 \mathrm{n} 3(\mathrm{EPA})(\mu \mathrm{g} * \mu \mathrm{gC}-1)$ & 0.009 & 0.007 & 0.011 & 0.006 & 0.016 & 0.011 \\
\hline 22:6n3 (DHA) ( $\left.\mu g^{*} \mu g C-1\right)$ & 0.007 & 0.005 & 0.017 & 0.017 & 0.024 & 0.039 \\
\hline C:N (mol*mol-1) & 7.59 & 0.66 & 10.14 & 2.65 & 8.03 & 1.72 \\
\hline $\mathrm{C}: \mathrm{P}\left(\mathrm{mol}^{*} \mathrm{~mol}-1\right)$ & 231.13 & 86.71 & 173.12 & 84.60 & 579.24 & 108.17 \\
\hline
\end{tabular}




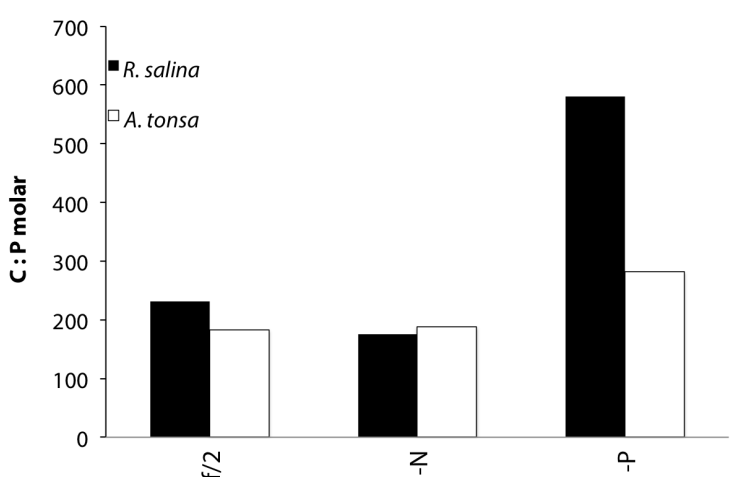

Figure 3. C:P ratios of R. salina grown on nutrient replete (f/2) and nutrient depleted (-P and $-\mathrm{N})$ conditions and $A$. tonsa reared on these algae.

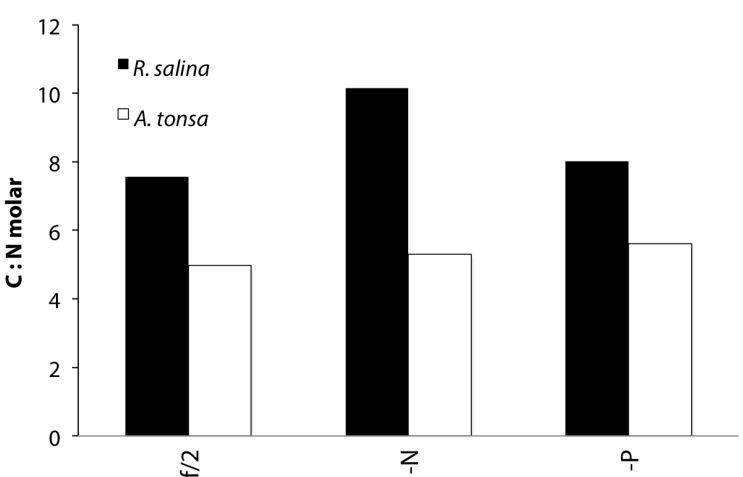

Figure 4. C:N ratios of R. salina grown on nutrient replete $(\mathrm{f} / 2)$ and nutrient depleted $(-\mathrm{P}$ and $-\mathrm{N})$ conditions and $A$. tonsa reared on these algae.

Table 2. Statistical information (one way Anova followed by Tukeys HSD test for unequal $\mathrm{n}$ ) on various fatty acid measures ( $\mu \mathrm{g}$ $F^{*} \mu$ g carbon-1) from phytoplankton reared on nutrient replete $(\mathrm{f} / 2)$ and nutrient depleted (-P and $\left.-\mathrm{N}\right)$ conditions.

\begin{tabular}{|c|c|c|c|c|c|c|c|c|}
\hline Measure & & SS & df & $\mathbf{F}$ & $\mathbf{p}$ & $f / 2$ vs $-P$ & $f / 2 v s-N$ & $-\mathbf{N}$ vs $-\mathrm{P}$ \\
\hline \multirow[t]{3}{*}{ Total Fatty acids } & Intercept & 0.741 & 1 & 192.020 & $>0.05$ & $<$ & $<$ & n.s. \\
\hline & Treatment & 0.096 & 2 & 12.449 & $>0.05$ & & & \\
\hline & Error & 0.201 & 52 & & & & & \\
\hline \multirow[t]{3}{*}{ Unsaturated FA } & Intercept & 0.258 & 1 & 101.979 & $>0.05$ & n.s. & $<$ & n.s. \\
\hline & Treatment & 0.046 & 2 & 9.119 & $>0.05$ & & & \\
\hline & Error & 0.131 & 52 & & & & & \\
\hline \multirow[t]{3}{*}{ 20:5n3 (EPA) } & Intercept & 0.008 & 1 & 117.231 & $>0.05$ & n.s. & $<$ & n.s. \\
\hline & Treatment & 0.001 & 2 & 4.047 & $>0.05$ & & & \\
\hline & Error & 0.003 & 52 & & & & & \\
\hline \multirow[t]{3}{*}{ 22:6n3 (DHA) } & Intercept & 0.013 & 1 & 22.242 & $>0.05$ & n.s. & n.s. & n.s. \\
\hline & Treatment & 0.003 & 2 & 2.283 & $>0.05$ & & & \\
\hline & Error & 0.031 & 52 & & & & & \\
\hline
\end{tabular}

(1962) or under nitrogen or phosphorus limitation. The phosphorus limited treatment was realized by adding all $\mathrm{f} / 2$ ingredients but phosphorus to sterile filtered natural seawater. This means that the phytoplankton could only use the phosphorus which was available in the seawater at the moment of filtration. Adding all of the other macro- and micronutrients assured a Liebig/Sprengel type phosphorus limitation (Sprengel 1839). Nitrogen limitation was realized by adding $20 \%$ of the $\mathrm{N}$ usually added to the $f / 2$ medium. The addition of some nitrogen was necessary to produce enough $\mathrm{N}$-limited phytoplankton to suit the experimental needs. In order to ensure constant algal quality, a new batch of algae was set up every day and cultured well into the stationary phase for the $\mathrm{N}$ and P limited cultures. F/2 algae were always harvested in the exponential growth phase (Malzahn et al. 2007; Malzahn and Boersma 2012; Malzahn et al. 2010).

The calanoid copepod Acartia tonsa was then fed on these nutrient manipulated phytoplankton for a predefined period, after which the copepods were analysed for elemental and biochemical composition as well as their developmental rates. Carbon and nitrogen were analysed by means of an elemental analyser. Phospho- rus was analysed as orthophosphate after acidic oxidative hydrolysis with $5 \% \mathrm{H}_{2} \mathrm{SO}_{4}$ (Grasshoff et al. 1999). Fatty acids were analysed as fatty acid methyl esters and gas chromatography (for details see Malzahn et al. 2007; Malzahn and Boersma 2012; Malzahn et al. 2010; Schoo et al. 2013a; Schoo et al. 2013b). Developmental rates were calculated by dividing the mean developmental stage by the age of the animals. Due to the isochronal growth of $A$. tonsa, which means that all developmental stages are equally long (Berggreen et al. 1988; Miller et al. 1977) under constant growth conditions, it was not necessary to apply a weighing factor for certain developmental stages.

\section{Results and Discussion}

The different nutrient limitations the algae were subjected to resulted in significant differences in carbon-to-nutrient ratios and fatty acid profiles. Phytoplankton significantly varied in their $\mathrm{C}: \mathrm{N}$ and $\mathrm{C}: \mathrm{P}$ ratios with respect to the nutrient treatment (Fig. 3, Fig. 4 and Table 1). The concentrations of the limiting elements were always lower than the non-limiting elements, pointing on 
Table 3. Statistical information (one way Anova followed by Tukeys HSD test for unequal n) on various fatty acid measures (expressed as \% of total FA) from phytoplankton reared on nutrient replete (f/2) and nutrient depleted (-P and -N) conditions.

\begin{tabular}{|c|c|c|c|c|c|c|c|c|}
\hline Measure & & SS & df & $\mathbf{F}$ & $\mathbf{p}$ & $f / 2$ vs $-P$ & $\mathbf{f} / 2$ vs $-\mathbf{N}$ & $-\mathbf{N}$ vs $-\mathbf{P}$ \\
\hline \multirow{3}{*}{$\%$ sum unsaturated FA } & Intercept & 143652.115 & 1 & 541.516 & $>0.05$ & n.s. & n.s. & n.s. \\
\hline & Treatment & 1388.279 & 2 & 2.617 & 0.08 & & & \\
\hline & Error & 13794.431 & 52 & & & & & \\
\hline \multirow[t]{3}{*}{$\%$ 20:5n3 (EPA) } & Intercept & 5270.416 & 1 & 243.938 & $>0.05$ & $>$ & $>$ & n.s. \\
\hline & Treatment & 269.813 & 2 & 6.244 & $>0.05$ & & & \\
\hline & Error & 1123.487 & 52 & & & & & \\
\hline \multirow[t]{3}{*}{ \% 22:6n3 (DHA) } & Intercept & 6571.439 & 1 & 61.112 & $>0.05$ & n.s. & n.s. & n.s. \\
\hline & Treatment & 62.834 & 2 & 0.292 & 0.75 & & & \\
\hline & Error & 5591.643 & 52 & & & & & \\
\hline
\end{tabular}

the non-homoeostatic nature of phytoplankton growth (Droop 1973; Droop 1974). The concentration of fatty acids also varied significantly with nutrient limitation, showing generally higher fatty acids concentrations when grown under nutrient limitation (Table 1 \& Table 2). Similar, as well as opposing patterns, have been reported for other phytoplankton species (Reitan et al. 1997). The majority of variability in fatty acid concentrations in general seems to be introduced by taxonomic group. However, the variance due to culture conditions can be substantial as well (Reitan et al. 1994). This species specific behaviour of altering fatty acid production with nutrient supply enables the keen aquaculturist to tailor single species cultures or even mixes of different phytoplankton species to suit the needs of live food and subsequently the larval fish. Considering fatty acids not as concentrations but as percentage of total fatty acids revealed a different picture (Table 3). Here we found fewer differences between the treatments, which indicate that fatty acids production might vary in quantity, but that the variation in relative proportions is less pronounced.

When copepods were fed such manipulated phytoplankton we found the same pattern of increased elemental ratios and fatty acid enriched copepods as when they were fed on phosphorus limited phytoplankton
(Figure 3 \& Figure 4, Table 4 \& Table 5). Looking at the relative contribution of fatty acids to the total fatty acid pool we found no differences between the treatments (Table 6), which points to the conservative nature of the propagation of fatty acids from one trophic level to the next (reviewed in Dalsgaard et al. 2003). However, not only did the fatty acid concentrations change in copepods when fed on nutrient limited phytoplankton, but so did the elemental composition. We found increased C:P ratios in copepods reared on phosphorus limited phytoplankton in several experiments (Malzahn et al. 2007; Malzahn and Boersma 2012; Schoo et al. 2010; Schoo et al. 2012; Schoo et al. 2013a). Consumers have a dome-shaped growth response to food carbon to phosphorus ratios, growth being carbon (energy) limited on the low C:P side and phosphorus limited on the high C:P side (Boersma and Elser 2006). High C:P ratios create problems because of the excess carbon which has to be taken up with every unit of phosphorus. The handling of the excess carbon seems to create costs high enough to significantly depress consumers' growth. The phytoplankton in our experiments showed superior fatty acid profiles and inferior C:P ratios under phosphorus limitation, the former known to accelerate growth (Dalsgaard et al. 2003; Engstrom-Ost et al. 2005; Izquierdo et al. 2000), the latter known to depress growth (Sterner

Table 4. Fatty acid concentrations and elemental ratios of copepods grown on nutrient replete (f/2) and nutrient depleted (-P and $-\mathrm{N}$ ) phytoplankton.

\begin{tabular}{|c|c|c|c|c|c|c|}
\hline Measure & $\mathbf{f} / 2$ & $+/-\mathbf{s d}$ & $-\mathbf{N}$ & $+/-\mathbf{s d}$ & $-\mathbf{P}$ & $+/-\mathbf{s d}$ \\
\hline $\begin{array}{l}\text { sum unsaturated FA } \\
\left(\mu g^{*} \mu g C^{-1}\right)\end{array}$ & 0.077 & 0.024 & 0.119 & 0.053 & 0.136 & 0.058 \\
\hline total FA $\left(\mu g^{*} \mu g C^{-1}\right)$ & 0.013 & 0.006 & 0.024 & 0.011 & 0.036 & 0.016 \\
\hline $\begin{array}{l}20: 5 \mathrm{n} 3(\mathrm{EPA}) \\
\left(\mu \mathrm{g}^{*} \mu \mathrm{gC}^{-1}\right)\end{array}$ & 0.002 & 0.003 & 0.003 & 0.004 & 0.006 & 0.003 \\
\hline $\begin{array}{l}22: 6 \mathrm{n} 3 \text { (DHA) } \\
\left(\mu \mathrm{g}^{*} \mu \mathrm{gC}^{-1}\right)\end{array}$ & 0.003 & 0.003 & 0.013 & 0.012 & 0.013 & 0.008 \\
\hline $\mathrm{C}: \mathrm{N}\left(\mathrm{mol}^{* *} \mathrm{~mol}^{-1}\right)$ & 4.989 & 0.127 & 5.303 & 0.628 & 5.617 & 0.580 \\
\hline $\mathrm{C}: \mathrm{P}\left(\mathrm{mol}^{*} \mathrm{~mol}^{-1}\right)$ & 180.912 & 39.585 & 186.018 & 65.281 & 280.917 & 96.898 \\
\hline
\end{tabular}


Table 5. Statistical information (one way Anova followed by Tukeys HSD test for unequal $\mathrm{n}$ ) on various fatty acid measures ( $\mu \mathrm{g}$ $\mathrm{FA}^{*} \mu \mathrm{g}$ carbon-1) from copepods reared on nutrient replete ( $\left.\mathrm{f} / 2\right)$ and nutrient depleted (-P and $\left.-\mathrm{N}\right)$ phytoplankton.

\begin{tabular}{|c|c|c|c|c|c|c|c|c|}
\hline \multicolumn{2}{|l|}{ Measure } & SS & df & $\mathbf{F}$ & $\mathbf{p}$ & $f / 2$ vs $-P$ & $\mathrm{f} / 2 \mathrm{vs}-\mathrm{N}$ & $-\mathrm{N}$ vs $-\mathrm{P}$ \\
\hline \multirow[t]{3}{*}{ tot. FA } & Intercept & 0.367 & 1 & 162.96 & $>0.05$ & n.s. & $<$ & n.s. \\
\hline & Treatment & 0.019 & 2 & 4.11 & $>0.05$ & & & \\
\hline & Error & 0.061 & 27 & & & & & \\
\hline \multirow[t]{3}{*}{$\begin{array}{l}\text { sum unsaturated } \\
\text { FA }\end{array}$} & Intercept & 0.018 & 1 & 125.44 & $>0.05$ & n.s. & $<$ & n.s. \\
\hline & Treatment & 0.003 & 2 & 9.52 & $>0.05$ & & & \\
\hline & Error & 0.004 & 27 & & & & & \\
\hline \multirow[t]{3}{*}{ 20:5n3 (EPA) } & Intercept & 0.000 & 1 & 39.92 & $>0.05$ & n.s. & $<$ & n.s. \\
\hline & Treatment & 0.000 & 2 & 3.53 & $>0.05$ & & & \\
\hline & Error & 0.000 & 27 & & & & & \\
\hline \multirow[t]{3}{*}{ 22:6n3 (DHA) } & Intercept & 0.003 & 1 & 35.42 & $>0.05$ & $<$ & $<$ & n.s. \\
\hline & Treatment & 0.001 & 2 & 4.20 & $>0.05$ & & & \\
\hline & Error & 0.002 & 27 & & & & & \\
\hline
\end{tabular}

Table 6. Statistical information (one way Anova followed by Tukeys HSD test for unequal $\mathrm{n}$ ) on various fatty acid measures (expressed as \% of total FA) from copepods reared on nutrient replete (f/2) and nutrient depleted (-P and $-\mathrm{N})$ phytoplankton.

\begin{tabular}{|c|c|c|c|c|c|c|c|c|}
\hline Measure & & SS & df & $\mathbf{F}$ & $\mathbf{p}$ & $f / 2$ vs $-P$ & f/2 vs $-\mathrm{N}$ & $-\mathrm{N}$ vs $-\mathrm{P}$ \\
\hline \multirow[t]{3}{*}{$\%$ sum unsaturated FA } & Intercept & 26614.51 & 1 & 360.38 & $>0.05$ & n.s. & $<$ & n.s. \\
\hline & Treatment & 1487.43 & 2 & 10.07 & $>0.05$ & & & \\
\hline & Error & 1920.13 & 26 & & & & & \\
\hline \multirow[t]{3}{*}{$\%$ 20:5n3 (EPA) } & Intercept & 259.71 & 1 & 59.66 & $>0.05$ & n.s. & n.s. & n.s. \\
\hline & Treatment & 12.12 & 2 & 1.39 & 0.267 & & & \\
\hline & Error & 113.18 & 26 & & & & & \\
\hline \multirow[t]{3}{*}{ \% 22:6n3 (DHA) } & Intercept & 1698.21 & 1 & 44.32 & $>0.05$ & n.s. & n.s. & n.s. \\
\hline & Treatment & 223.30 & 2 & 2.91 & 0.072 & & & \\
\hline & Error & 996.19 & 26 & & & & & \\
\hline
\end{tabular}

1993; Sterner et al. 1993; Sterner and Hessen 1994). The question arising from this is distinguishing which factor is more important for e.g. larval fish growth. The unique biochemical composition of the phytoplankter $R$. salina and the relatively strong conservation of fatty acids as well as C:P signals in the copepod $A$. tonsa allowed us to test this. In all of the above mentioned experiments high copepod C:P resulted in reduced growth rates in larval herring (Malzahn et al. 2007), gelatinous zooplankton (Schoo et al. 2010) and larval European lobster (Schoo et al. 2012; Schoo et al. 2013a). This finding leads to the conclusion that mineral requirements have to be fulfilled first before biochemical requirements like fatty acids can promote growth. Consequently, not one single measure should be the focus when optimizing live feeds for aquaculture, but a more holistic approach will lead to better results.

\section{References}

Awaiss, A., P. Kestemont, and J. C. Micha. 1992. Nutritional suitability of the rotifer, Brachionus calyciflorus Pallas for rearing freshwater fish larvae. Journal of Applied Ichthyology 8: 263-270.

Beaugrand, G., K. M. Brander, J. A. Lindley, S. Souissi, and P. C. Reid. 2003. Plankton effect on cod recruitment in the North Sea. Nature 426: 661-664.

Beaugrand, G., P. C. Reid, F. Ibanez, J. A. Lindley, and M. Edwards. 2002. Reorganization of North Atlantic marine copepod biodiversity and climate. Science 296: 1692-1694.

Berggreen, U., B. Hansen, and T. Kiørboe. 1988. Food size spectra, ingestion and growth of the copepod Acartia tonsa during development: Implications for determination of copepod production. Marine Biology 99: 341.

Boersma, M. and J. J. Elser. 2006. Too much of a good thing: On stoichiometrically balanced diets and maximal growth. Ecology 87: 1325-1330. 
Buskey, E. J., C. Coulter, and S. Strom. 1993. Locomotory patterns of microzooplankton: potential effects on food selectivity of larval fish. Bulletin of Marine Science 53: 29-43.

Dalsgaard, J., M. St.John, D. C. Müller-Navarra, and W. Hagen. 2003. Fatty acid trophic markers in the pelagic marine environment: a synthesis of applications and critical review of suitability. Advances in Marine Biology 46: 225-340.

Doi, M., J. D. Toledo, M. S. N. Golez, M. A. de los Santos, and A. Ohno. 1997. Preliminary investigation of feeding performance of larvae of early redspotted grouper, Epinephelus coioides, reared with mixed zooplankton. Hydrobiologia 358: 259-263.

Droop, M. R. 1973. Some thoughts on nutrient limitation in algae. Journal of Phycology 9: 264.

Droop, M. R. 1974. The nutrient status of algal cells in continuous culture. Journal of the Marine Biological Association of the United Kingdom 54: 825-855.

Engstrom-Ost, J., M. Lehtiniemi, S. H. Jonasdottir, and M. Viitasalo. 2005. Growth of pike larvae (Esox lucius) under different conditions of food quality and salinity. Ecology of Freshwater Fish 14: 385-393.

FAO. Fisheries Department, Fishery Information, Data and Statistics Unit, Rome Italy.

Gismervik, I. 1997a. Implications of zooplankton stoichiometry on distribution of $\mathrm{N}$ and $\mathrm{P}$ among planktonic size fractions. Journal of Plankton Research 19: 343-356.

Gismervik, I. 1997b. Stoichiometry of some marine planktonic crustaceans. Journal of Plankton Research 19: $279-285$

Grasshoff, K., K. Kremling, and M. Erhardt. 1999. Methods of seawater analysis. 3 edition. Wiley-VCH, Weinheim, Germany.

Greve, W., F. Reiners, J. Nast, and S. Hoffmann. 2004. Helgoland Roads meso- and macrozooplankton time-series 1974 to 2004: Lessons from 30 years of single spot, high frequency sampling at the only offshore island of the North Sea. Helgoland Marine Research 58: 274-288.

Guillard, R. and J. Ryther. 1962. Studies of marine planktonic diatoms. Canadian Journal of Microbiology 8: 229-239.

Izquierdo, M. S., J. Socorro, L. Arantzamendi, and C. M. Hernandez-Cruz. 2000. Recent advances in lipid nutrition in fish larvae. Fish Physiology and Biochemistry 22: 97-107.

Lavens, P. and P. Sorgeloos. 1996. Manual on the Production and use of live food for aquaculture. FAO Fisheries Technical Papers 361: 305.

Lavens, P., P. Sorgeloos, P. Dheit, and B. Devress. 1994. Larval Foods. Pages 373-397 in R. J. Roberts and N.
R. Bromage, editors. Broodstock management and egg and larval quality. Blackwell Science Ltd., Oxford, UK.

Lee, S.-M. 2001. Review of the lipid and essential fatty acid requirement of rockfish (Sebastes schlegeli). Aquaculture Research 32: 8-17.

Malzahn, A. M., N. Aberle, C. Clemmesen, and M. Boersma. 2007. Nutrient limitation of primary producers affects planktivorous fish condition. Limnology and Oceanography 52: 2062-2071.

Malzahn, A. M. and M. Boersma. 2012. Effects of poor food quality on copepod growth are dose dependent and non-reversible. Oikos 121: 1408-1416.

Malzahn, A. M., F. M. Hantzsche, K. L. Schoo, M. Boersma, and N. Aberle. 2010. Differential effects of nutrient-limited primary production on primary, secondary or tertiary consumers. Oecologia 162: 35-48.

Miller, C. B., J. K. Johnson, and D. R. Heinle. 1977. Growth rules in the marine copepod genus Acartia. Limnology and Oceanography 22: 326-335.

Monteleone, D. M. and W. T. Peterson. 1986. Feeding ecology of American sand lance Ammodytes americanus larvae from Long Island Sound. Marine Ecology Progress Series 30: 133-143.

Otterlei, E., G. Nyhammer, A. Folkvord, and S. O. Stefansson. 1999. Temperature- and size-dependent growth of larval and early juvenile Atlantic cod ( $G a-$ dus morhua): a comparative study of Norwegian coastal cod and northeast Arctic cod. Canadian Journal of Fisheries and Aquatic Sciences 56: 2099e2211.

Paulsen, M., C. Clemmesen, and A. M. Malzahn. 2014a. Essential fatty acid availability (docosahexaeonic acid, DHA) affects growth of larval herring in the field. Marine Biology 161: 239-244.

Paulsen, M., C. Hammer, A. M. Malzahn, P. Polte, C. Von Dorrein, and C. Clemmesen. 2014b. Nutritional situation for larval Atlantic herring (Clupea harengus L.) in two nursery areas in the western Baltic Sea ICES Journal of Marine Science 71: 991-1000.

Pepin, P. and R. W. Penney. 1997. Patterns of prey size and taxonomic composition in larval fish: are there general size-dependent models? Journal of Fish Biology 51: 84-100.

Reitan, K. I., J. R. Rainuzzo, G. Oie, and Y. Olsen. 1997. A review of the nutritional effects of algae in marine fish larvae. Aquaculture 155: 207-221.

Reitan, K. I., J. R. Rainuzzo, and Y. Olsen. 1994. Effect of nutrient limitation on fatty acid and lipid content of marine microalgae. Journal of Phycology 30: 972-979.

Schoo, K. L., N. Aberle, A. M. Malzahn, and M. Boersma. 2010. Does the nutrient stoichiometry of primary producers affect the secondary consumer Pleurobrachia pileus? Aquatic Ecology 44: 233-242 
Schoo, K. L., N. Aberle, A. M. Malzahn, and M. Boersma. 2012. Food quality affects secondary consumers even at low quantities: An experimental test with larval european lobster. PloS ONE 7: e33550.

Schoo, K. L., N. Aberle, A. M. Malzahn, I. Schmalenbach, and M. Boersma. 2014. The reaction of European lobster larvae (Homarus gammarus) to different quality food: effects of ontogenetic shifts and pre-feeding history. Oecologia 174: 581-594.

Schoo, K. L., A. M. Malzahn, S. Schnell, E. M. Krause, and M. Boersma. 2013. Increased carbon dioxide availability impacts a marine planktonic herbivore. Marine Biology 160: 2145-2155.

Shao, Q., J. Ma, Z. Xu, W. Hu, J. Xu, and S. Xie. 2008. Dietary phosphorus requirement of juvenile black seabream, Sparus macrocephalus. Aquaculture 277: 92-100.

Sprengel, C. 1839. Die Lehre vom Dünger oder Beschreibung aller bei der Landwirtschaft gebräuchlicher vegetablilischer, animalischer und mineralischer Düngermaterialien, nebst Erklärung ihrer Wirkungsart., Leipzig.

Sterner, R. W. 1993. Daphnia growth on varying quality of Scenedesmus: Mineral limitation of zooplankton. Ecology 74: 2351-2360.

Sterner, R. W., D. D. Hagemeier, W. L. Smith, and R. F. Smith. 1993. Phytoplankton nutrient limitation and food quality for Daphnia. Limnology and Oceanography 38: 857-871.

Sterner, R. W. and D. O. Hessen. 1994. Algal nutrient limitation and the nutrition of aquatic herbivores. Annual Review of Ecology and Systematics 25: 1-29.

Stoecker, D. K. and J. J. Govoni. 1984. Food selection by young larval Gulf Menhaden (Brevoortia patronus). Marine Biology 80: 299-306.

Stottrup, J. 2000. The elusive copepods: their production and suitability in marine aquaculture. Aquaculture Research 31: 703-711.
Støttrup, J. G. and N. H. Norsker. 1997. Production and use of copepods in marine fish larviculture. Aquaculture 155: 231-247.

Sugama, K., M. A. Rimmer, S. Ismi, I. Koesharyani, K. Suwirya, N. A. Giri, and V. R. Alava. 2012. Hatchery management of tiger grouper (Epinephelus fuscoguttatus): a best-practice manual. Australian Centre for International Agricultural Research, Canberra, p66.

Toledo, J. D., N. B. Caberoy, and G. F. Quinitio. 2004. Environmental factors affecting embryonic development, hatching and survival of early stage lavae of the grouper (Epinephelus coioides). In: M. A. Rimmer and S. W. McBride, K.C. , editors. ACIAR Monograph No. 110.: Advances in grouper aquaculture. Australian Centre for International Agricultural Research, Canberra, pages 10-16.

Van der Meeren, T. 1991. Selective feeding and prediction of food consumption in turbot larvae (Scophthalmus maximus L.) reared on the rotifer Brachionus plicatilis and natural zooplankton. Aquaculture 93: 35-55.

Villar-Argaiz, M., J. M. Medina-Sanchez, and P. Carrillo. 2002. Linking life history strategies and ontogeny in crustacean zooplankton: Implications for homeostasis. Ecology 83: 1899-1914.

Villar-Argaiz, M. and R. W. Sterner. 2002. Life history bottlenecks in Diaptomus clavipes induced by phosphorus-limited algae. Limnology and Oceanography 47: 1229-1233.

Von Herbing, H. and S. Gallagher. 2000. Foraging behavior in early Atlantic cod larvae (Gadhus morhua) feeding on a protozoan (Balanion sp.) and a copepod nauplius (Pseudodiaptomus sp.). Marine Biology 136: 591-602. 